\title{
Managing The Re-Employment Of Military Veterans Through The Transition Assistance Program (TAP)
}

Judson Faurer, Metropolitan State University of Denver, USA Apryl Rogers-Brodersen, Metropolitan State University of Denver, USA Paul Bailie, University of Phoenix, USA

\begin{abstract}
With the drawdown of troops in Iraq and Afghanistan and a \$1.05 trillion dollar cut in the Department of Defense budget over the next ten years, tens of thousands of veterans are flooding the job market at a time when millions of civilians cannot find employment. To fight this high number of unemployed veterans Congress passed the Veterans Employment Bill of President Obama's Jobs Bill in November 2011. This paper discusses the government sponsored military veteran Transition Assistance Program's (TAP) effectiveness in reducing the veteran unemployment rate and presents the results of a survey of 350 Army personnel's perceptions of the utility of the services offered through the TAP.
\end{abstract}

Keywords: Transition Assistance Program (TAP); Military Veteran Employment

\section{INTRODUCTION}

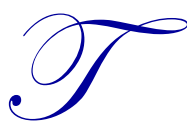

hroughout the nation's existence there have been periods of armed conflict with its citizens either being conscripted or volunteering to serve in the military. With resolution of the hostilities, uniformed personnel, in large numbers, returned to civilian life. Once again history repeats itself. After ten years of war in Iraq, President Obama officially announced in October 2011 that the remaining troops will withdraw from the region before the end of the year. His announcement of the withdrawal from Iraq terminated the mobilization orders for thousands of active duty and reserve soldiers that have spent the last year training and preparing for operations in a combat zone. A large number of units that were set to deploy have individuals within that were not full-time active duty military personnel. Some were part-time citizen soldiers that held jobs in a civilian sector and others were unemployed awaiting a return from contingency operations overseas to seek employment. Other military personnel not employed in the civilian section and working full time for the military in preparation for mobilization are left hopeless. Many of these military personnel did not seek employment due to the short timeframe until deployment. Now these individuals are scrambling to find a job in a market with meager employment opportunities. This termination order has also left employers disgruntled because temporary employees have been hired to replace deploying citizen soldiers that are returning or no longer set to deploy.

For the active duty military, the reduction-in-force notifications have already started to circulate. Soldiers that have made the sacrifice to serve and are good at performing their military jobs have received notifications that their services are no longer required and their contracts will terminate within a year. For others that have already left the service, many are still struggling to find employment. Currently there are almost one million unemployed veterans looking for employment [1]. With the drawdown of troops in Iraq and Afghanistan and a $\$ 1.05$ trillion dollar cut in the Department of Defense budget over the next ten years, tens of thousands of veterans are flooding the job market at a time when millions of civilians cannot find employment [1]. The Army announced plans to reduce its head count by 50,000 soldiers and the number is expected to grow [3]. 
Although a Transition Assistance Program (TAP) was initiated in Congress in the early 1990s, its effectiveness has been limited and unemployment rates among veterans remain high. Perhaps more important is the fact that the program does not continue what the all volunteer military service promised: a life of continued selfimprovement. Chronic unemployment persists among former service members and at much higher rates than equivalent non-military demographic groups. The unemployment rate for returning Iraq and Afghanistan veterans was at 21.6 percent in 2009 compared to the 8.6 percent national rate announced on December 2, 2011 [4]. According to a 2010 poll conducted by the Society for Human Resource Management in 2010, 60 percent of employers surveyed felt that veterans had difficulty translating military experiences into civilian job experience. This begs the question as to whether the TAP is working for transitioning service members.

\section{Background}

Historically, during every major American conflict, the Department of Defense has added additional personnel to its force structure to meet the demands at home and abroad. Upon the completions of each campaign, the Department of Defense initiates a reduction-in-force to realign its spending with a non-wartime budget. When Congress established the Transition Assistance Program in 1990, significant reductions in military force levels were expected [9]. The law noted that many of these service personnel specialized in critical skills that would not transfer to the civilian workforce. Transition assistance to include employment and job training services was intended to help such service members make suitable educational and career choices as they readjusted to civilian life [9].

In August 2011, President Obama visited the Washington Navy Yard and directed the Departments of Defense and Veteran's Affairs to lead a task force to develop the first major redesign of the military's Transition Assistance Program (TAP) in over 20 years.

With a long drawn-out deficit cut battle on Capitol Hill and Congress' inability to compromise on which programs to reduce spending; it is feared that the automatic spending cuts for the Department of Defense, in addition to $\$ 450$ billion already agreed upon spending cuts, will cause the Pentagon to cut deeper than any other postwar realignment. As the Department of Defense moves forward it will need to decide whether it is better to preserve the size of the existing force structure or to invest in the technological advances created during ten years of combat proven testing. It is known that the Department of Defense will need to reduce its head count to prewar level, but it will face a moral dilemma to choose between personnel and technology. It is feared as in the past that the Pentagon will choose to preserve technology or a mix of technology and personnel resulting in a significant number of unemployed veterans. In an effort to mitigate these effects, congress passed the Veterans Employment Bill of President Obama's Jobs Bill in November 2011. This bill will provide tax breaks for businesses that employ unemployed veterans, increase education benefits for job training programs, and create improvements in the transition assistance program.

\section{SAMPLE RESULTS: PERCEIVED UTILITY OF THE TAP}

To garner an insight into the program, a sample of 350 Army personnel available to the researcher who have or could have used the TAP were surveyed. The full survey and responses are presented in Appendix A. Findings from the study found that, of the 227 respondents (65\%) who reported they used the services offered by the TAP, $75 \%$ were still on active duty when they enrolled; $15 \%$ of the participants were already discharged or disabled; and $10 \%$ were reservists. Eighty four percent of the participants who used the services found employment as a result of using TAP while only $16 \%$ did not. Further, $88 \%$ would recommend the TAP program to a fellow veteran. With respect to services used, it is interesting to note that $90 \%$ of the participants used the program to assist with writing a resume and cover letters, $75 \%$ of the participants worked one-on-one with job counselors to search for employment, $38 \%$ found jobs at the program's supported job fairs, $26 \%$ completed a certificate exam to obtain a civilian occupational standard certificate for their military skill, $24 \%$ participated in the challenge exam to receive civilian educational credits for their military training, and a small percentage participated in the vocational certification programs. Results of the study indicated that the favorable attitude of participants toward the program seemed to correlate with the number of years in the service. A majority of participants that participated in the program had been in the service for at least five but less than 10 years. However, participants that had served in the Army for more than 10-years found the most benefits from the program, and participants that had served less than two years appeared to derive the least benefit or did not participate. 
Unrelated to the sample survey discussed above, but of interest, some 3,000 Army, Navy, Marine Corps, and Air Force ex-service members, Army civilians, and spouses of Army ex-service members who made the transition back to civilian life between October 1992 and September 1993 participated in computer-assisted interviews in late 1994. Among the outcome measures were annual earnings and ratings of preparedness for the job market. Multivariate analyses were conducted to assess the relative impact of various personal, military, and transitional-related characteristics on these outcomes. The results indicated that the more job research assistance services individuals received and the more satisfied they were with such services, the more prepared they felt and the greater success they achieved in the civilian labor market (Society of Human Resource Management, 2010).

\section{LIMITATIONS TO PROGRAM SUCCESS}

As with many government assistance programs aimed at aiding the recipients, the scope of the bureaucracies involved in the programs, in and of themselves, become limiting factors to the intended success of established programs. Three separate agencies are assigned responsibility for military transition: Department of Defense, Department of Veterans Affairs and the Department of Labor and functional responsibility is shared across the 50 states. Funds are transferred to each state to operate veterans' employment assistance centers at state employment agencies (Perkins, 2012). Such an arrangement diffuses program responsibility. Although each branch of the military provides the required pre-separation counseling and offers workshops focusing on employment assistance, not all service members participate. Branches also have considerable flexibility in designing their programs, resulting in content and delivery variances (Government Accounting Office, 2002).

Evaluating the overall success of the TAP is hindered by the varied military experiences of the members in each branch. Those members transitioning from combat-related jobs with limited transferability to jobs in the civilian labor market may require more tailored counseling and more extensive workshops than those originally designed thus adding to the cost. The scheduling of the delivery of transition assistance can also be a limiting factor to program success. The Air Force, for instance, integrates transition assistance throughout an airman's military career, the Navy provides transition assistance earlier than the law requires, the Army supplements DOD transition assistance funds to provide additional one-on-one counseling, and the Coast Guard hires contractors to facilitate its workshops [11]. Access to transition assistance can vary significantly because of location remoteness, mission dictates, or work priorities. Lastly, limitations on evaluation of TAP effectiveness are affected by data collection inadequacies which do not allow for comparison across branches (GAO, 2002). Following up with separated service members is a challenge but even more limiting in evaluating effectiveness is the potential shift in service's emphasis from transition assistance to retention [11].

\section{CONCLUSIONS/RECOMMENDATIONS}

Evaluation of the program by an independent organization found that veterans who used the services of the TAP found employment three weeks earlier on average than those who did not [10]. According to Paul Rieckhoff, founder and executive director of Iraq and Afghanistan Veterans of America (IAVA), "there is no silver bullet solution for veteran unemployment" but if the nation wants to support veterans, hire them [7]. In July 2012, President Obama announced the TAP would be moved into the $21^{\text {st }}$ century with more individualized assistance to help separating service members with their personal post-military goals. This includes more one-on-one counseling, more follow-up, and separate tracts for those attending college, those wanting to start their own business, and those wanting more focus on the mechanics of getting a job. The enhanced program also eliminates the "Death by PowerPoint" briefing workshop and adopted the new name TAPGPS for "goals planning and success" [8].

Recommendations that could combat the problem of veterans' unemployment include increasing the Department of Labor budget for veterans [2] mandating the use of the TAP by all branches of the military for servicemen, improving workshop availability times, and an official federally supported system of certifying or licensing military skills in line with civilian vocations. Additionally, the use of talented facilitators and local HR professionals to co-facilitate the scheduled TAP classes and workshops, encouraging employers to standardize their own job descriptions to better convey job requirements, and enhanced understanding of the skills translators on Military.com as a useful tool could evoke greater participation by soon to be veterans and enhance the program's effectiveness. Those involved in establishing and conducting the TAP program and those who it is intended to serve 
are often not fully aware of one another's needs and offerings. The government's efforts to date have established a reasonably workable solution to facilitating the transition of veterans back to the civilian workforce but the numbers of transitioning veterans is currently growing and the available job market and general employment continues to be a major concern of the federal administration. Further refinement of the program is needed to ensure it attaining its intended goals. Perhaps priority hiring should be given to veterans and even greater attention given to the future if and when armed conflicts sound the Klaxon once again for those willing to transition from civilian life to the military and back in service to the country.

\section{AUTHOR INFORMATION}

Judson Faurer, Ph.D., Metropolitan State University of Denver, Campus Box 78, P.O. Box 73362, Denver, CO 80217, USA. Telephone: 303-494-3076. Dr. Faurer combines over thirty years of management experience and observation along with a varied education (B.S. - U.S. Military Academy; MBA - Ohio State University; Ph.D. in Education - University of Denver) and an interactive teaching style to provide students with a practical insight into organizational management practices. E-mail: faurerj@msudenver.edu (Corresponding author)

Apryl Rogers-Brodersen, Ph.D., Metropolitan State University of Denver, Campus Box 78, P.O. Box 73362, Denver, CO 80217, USA. Telephone: 303-204-2338. Dr. Rogers-Brodersen has a Ph.D. in Industrial/Organization Psychology from Colorado State University. She has worked as a consultant and is a member of the Society for Industrial and Organizational Psychology and the Colorado/Wyoming Society for Industrial and Organizational Psychologists. She teaches numerous courses in human resources. E-mail: $\underline{\text { arogersb@ msudenver.edu }}$

Paul Bailie, MBA student, University of Phoenix, USA.

\section{REFERENCES}

1. Alper, A. (2011). Soldiers return home to a land with limited job opportunities. Retrieved from http://jobs.aol.com/articles/2011/08/04/u-s-soldiers-return-home-to-a-land-with-limited-job-opportunties

2. Embree, T. (2011). Iraq and Afghanistan veterans of American-status of veterans unemployment. Retrieved January 4, 2012 from http://iava.org/content/status veterans unemployment

3. Larter, D. (2011). Oderino: Cuts could shrink guard, reserve. Army Times. Retrieved from http://www.armytimes.com/news/2011/11

4. Maze, R. (2011). Congress passes veterans employment bill. Army Times. Retrieved from http://Armytimes.com/news/2011/11/military- congress passes veterans employment-bill-111611/

5. Perkins, W. (2012). The Military transition assistance program (TAP)? Retrieved from http://EzineArticles.com

6. Society of Human Resource Management. (2010). Employing Military personnel and recruiting veterans attitudes and practices. Retrieved from http://www.shram.org/Research/Survey/Findings/articles

7. Staff writer. (2011). Obama unveils major job initiative for vets. Army Times. Retrieved from http://www.armytimes.com/news/2011/08

8. Staff writer. (2012). More assistance expected with update to TAP. Air Force Times. Retrieved from http://www.airforcetimes.com/news/2012/07

9. The American War Library. (2008). What is a veteran? Retrieved from http://www.americanwarlibrary.com/whatvet.htm

10. United States Department of Labor. (2012). Vets fact sheet 1 - transition assistance program. Retrieved January 4, 2012 from http://www.dol.gov/vets/programs/tap/tap_fs.htm

11. United States Government Accounting Office (2002). Military and veterans' benefits: Observations on the Transition Assistance Program, GAO-02-915T.

12. United States Government Accounting Office (2005). Military and veterans' benefits: Enhanced services could improve transition assistance for Reserves and National Guard, GAO-05-544.

13. Veterans Today (2012). Redesigned Transition Assistance Program announced. Retrieved from http://www.veteranstoday.com/2012/07/23/redesigned 


\section{APPENDIX A - VETERAN'S SURVEY}

1. Have you ever used any government sponsored programs to assist with finding employment?
a. Yes $-58 \%$

b. No $-42 \%$

2. Have you used the Transition Assistance Program (TAP) sponsored by the government?
a. Yes $-65 \%$

b. No- $35 \%$

3. Which of the TAP services did you take advantage of?
a. Resume and cover letter services
b. Job Fairs
$\frac{90 \%}{38 \%}$
c. Challenge Exam-civilian education credits
$\frac{38 \%}{24 \%}$
d. Certification Exam- civilian occupational standard certificate
e. Vocational certification programs
f. Online Learning Events
g. On Demand Career Transition Courses
h. One on One Counselors

4. Please rank programs in order of usefulness from 1 to 8 ? Percentage that rated program as first choice.
a. Resume and cover letter services
b. Job Fairs
$\underline{64 \%}$
c. Challenge Exam-civilian education credits
d. Certification Exam- civilian occupational standard certificate
e. Vocational certification programs
f. Online Learning Events
g. On Demand Career Transition Courses
$\underline{10 \%}$
. One on One Counselors

$\frac{\frac{5 \%}{5 \%}}{\frac{2 \%}{2 \%}}$

5. Did you find employment as a result of using TAP?
a. Yes $-84 \%$
b. No $-16 \%$

6. How long did it take to find employment?
a. 3-6 months $-15 \%$
b. 6-9 months $-50 \%$
c. $9-12$ months $-23 \%$
d. Greater than a year $-12 \%$

7. Have you decided to continue with your civilian education instead of seeking employment?
a. Yes $-26 \%$
b. No $-74 \%$

8. The program a useful resource to you in searching for employment?
a. Strongly agree $-83 \%$
b. Agree $-7 \%$
c. Neither agree nor disagree $-1 \%$
d. Disagree $-7 \%$
e. Strongly Disagree $-2 \%$

9. The program was easily accessible?
a. Strongly agree $-82 \%$
b. Agree $-7 \%$
c. Neither agree nor disagree $-41 \%$
d. Disagree $-5 \%$
e. Strongly Disagree $-2 \%$

10. Would you recommend the TAP program to a fellow veteran?
a. Yes $-88 \%$
b. No- $12 \%$ 


\section{NOTES}

